\title{
Diplomasi Publik Organisasi Nonpemerintah dalam Membangun Citra Indonesia: Studi Kegiatan "Koalisi untuk Kebebasan Informasi"
}

\author{
H. A. Saefudin
}

\begin{abstract}
The research is aimed to find out the "Coalition for Freedom of Information" activity, or Coalition, that can be categorized public diplomacy, its relationship with implementing the government as the requirement to realize the good governance, and to get to know the relationship between good governance and the image building of Indonesia. The principles of public relations are used as the approach in analyzing the phenomenon of public diplomacy used by Coalition. This research was conducted by using the qualitative approach through constructivist paradigm toward the Coalition attitude in applying the public diplomacy. This research used both the key and supporting informa collecting was conducted by interview, observation, participation, and documentary study about the Coalition activity as well as the delphi technique. The data analysis was carried out as long as the research went on through the intersubjective commitment to focus being researched. The research gained some findings which involved: (a) The "Coalition for Freedom of Information" activity in public diplomacy can be done by the public relations approach using some activity categories, (b) The "Coalition for freedom of information" performance is focused on the efforts to uphold the law concerning freedom of access to public information in supporting the realization of good governance, (c) The public diplomacy activity applied by the Coalition through its advocacy was considered successful which can be seen by the local government rules concerning the implementation of participative and transparent government, (d) The model with the integrated public diplomacy potency and the synergy between the state actor and the non-state actor possessing their own structural authority and legality in the information service system for all public elements can build the positive image of Indonesia
\end{abstract}

Kata kunci: kebebasan informasi, diplomasi publik, organisasi nonpemerintah

\section{Pendahuluan}

Political and Economic Risk Consultancy di tahun 2003 mencatat, Indonesia menempati urutan teratas negara paling korup di Asia dan menempati urutan ke-96 dari 100 negara di tingkat internasional. International Transparency dalam penelitiannya juga mencatat, Indonesia di tahun 2004, menempati peringkat kelima terkorup di antara
143 negara di dunia, dengan nilai indeks 2,0 tahun 2005 menempati urutan keenam terkorup dari 158 negara yang disurvei, dengan nilai indeks 2,2; dan tahun 2006, menempati urutan ketujuh dari 163 negara yang disurvei dengan nilai indeks 2,4.

Di bidang ekonomi, dilaporkan Asian Intelligence, Investasi asing di Indonesia, sejak 1997, terus minus. Peringkat daya saing ekonomi Indonesia pada 2005, berada pada posisi ke-69 dari 107 
negara yang disurvei Forum Ekonomi Dunia (World Economic Forum).

Peringkat daya saing di sektor industri, menurut International Institute for Management Development, mengalami penurunan pada setiap tahun, sejak 2001, yaitu peringkat ke-46, secara berurut menjadi peringkat ke-47, 57, 58, 59, dan ke60 pada 2006. Demikian juga dalam hal kemudahan memulai usaha, oleh International Finance Corporation dan World Bank, Indonesia dinyatakan berada diperingkat ke-135 dari 175 negara.

Data, informasi, kejadian, dan peristiwa yang menunjukkan kondisi krisis Indonesia dalam berbagai bidang, telah menjadi suatu realitas dan menjadi gambaran yang bermakna tentang Indonesia. Gambaran yang bermakna itu, disebut citra.

Data, informasi, kejadian, dan peristiwa yang menunjukkan kondisi krisis Indonesia, yang kemudian dikomunikasikan secara meluas melalui berbagai bentuk dan media komunikasi kepada khalayak di dalam negeri dan di luar negeri, menurut Roberts, dapat mempengaruhi cara khalayak mengorganisasikan citra tentang kondisi krisis Indonesia, dan "citra inilah yang mempengaruhi cara khalayak tersebut bertindak" (Rakhmat, 2004:224). Pencitraan yang baik terhadap suatu negara atau bangsa dapat memotivasi bangsa lain untuk bekerja sama yang saling menguntungkan, sehingga dapat meningkatkan kesejahteraan negara atau bangsa yang bersangkutan.

Diplomasi sebagai proses kunci melaksanakan komunikasi dan negosiasi bangsa Indonesia dengan bangsa lain untuk memperoleh bantuan internasional, memerlukan keterlibatan seluruh komponen bangsa Indonesia untuk berdiplomasi. Tidak hanya dilakukan antara pemerintah Indonesia dengan pemerintah negara lain tanpa melibatkan keikutsertaan masyarakat. Diplomasi hubungannya dengan perbaikan citra, sebagaimana dikemukakan Ali Alatas, bahwa, untuk mengatasi citra Indonesia yang buruk di luar negeri-sebagai akibat kekacauan yang menyebabkan investor enggan kembali, yang pada gilirannya memperlambat pemulihan ekonomi, diperlukan suatu upaya diplomasi yang benarbenar komprehensif dan terpadu². Untuk memperoleh keberhasilan dari sebuah diplomasi ini, maka tidak akan terlepas dari kebijakan melibatkan komponen masyarakat secara intensif, seperti pelibatan organisasi nonpemerintah untuk membangun citra Indonesia.

Organisasi nonpemerintah (Ornop) atau disebut juga Lembaga Swadaya Masyarakat (LSM), mulai tumbuh dan berkembang di Indonesia pada awal 1970-an, yang mempunyai peran mengawasi peran negara serta mengajukan alternatif gagasan, seperti diperankan LP3ES. Para pengamat berargumentasi, organisasi nonpemerintah tumbuh sebagai suatu respons terhadap kontrol yang ketat dari suatu sistem politik yang tidak memberikan kebebasan kepada partai politik sebagai sebuah mimbar yang bebas. ${ }^{3}$ Permasalahan yang menyangkut keterlibatan komponen-komponen masyarakat Indonesia dalam diplomasi dengan masyarakat di luar negeri, dalam membangun citra Indonesia, kesemuanya termasuk ke dalam ruang lingkup kajian public relations, sebagai salah satu profesi dalam ilmu komunikasi.

Atas dasar lingkup permasalahan termasuk dalam kajian public relations, dan diplomasi yang melibatkan keikutsertaan komponen bangsa di luar pemerintahan yang disebut dengan istilah diplomasi publik itu, maka studi yang dilakukan merupakan studi tentang "Koalisi untuk Kebebasan Informasi” sebagai sebuah koalisi dari berbagai Ornop dalam menunjang terwujudnya good governance melalui pendekatan public relations. Melalui studi ini diharapkan dapat ditemukan model diplomasi publik dengan pendekatan public relations dalam membangun citra Indonesia.

Berdasarkan latar belakang di atas, maka penelitian ini difokuskan secara lebih spesifik kepada diplomasi publik yang banyak diperankan oleh "Koalisi untuk Kebebasan Informasi" atau Koalisi, dalam upaya memperjuangkan kebebasan memperoleh informasi publik. Peran dan kinerja Koalisi ini akan ditelaah terhadap upaya-upaya menunjang pembangunan citra Indonesia melalui pendekatan-pendekatan yang diasumsikan banyak menggunakan pendekatan public relations.

Selanjutnya untuk memperoleh kajian secara 
terfokus, maka identifikasi masalah dalam penelitian ini dirumuskan sebagai berikut.

(1) Bagaimana kegiatan "Koalisi untuk Kebebasan Informasi" dalam diplomasi publik.

(2) Bagaimana kinerja "Koalisi untuk Kebebasan Informasi" dalam perwujudan good governance.

(3) Bagaimana kegiatan diplomasi publik yang dilakukan "Koalisi untuk Kebebasan Informasi" dalam pembangunan citra Indonesia.

(4) Model diplomasi publik seperti apa yang mampu menghasilkan pembangunan citra Indonesia.

\section{Objek dan Metode Penelitian}

Objek penelitian adalah kegiatan "Diplomasi publik oleh Koalisi untuk Kebebasan Informasi melalui pendekatan public relations dalam menunjang terwujudnya good governance." Penelitian ini menggunakan pendekatan penelitian kualitatif melalui paradigma konstruktivisme. Alasan pemilihan pendekatan penelitian tersebut dikarenakan bahwa studi ini terfokus pada perilaku komunikasi melalui pendekatan public relations yang ditelaah melalui perilaku komunikasi Koalisi dalam perjuangannya untuk melahirkan UndangUndang Kebebasasan Memperoleh Informasi Publik yang dapat mewujudkan pemerintahan yang terbuka sehingga menghasilkan citra positif Indonesia.

Sumber data yang termasuk ke dalam sumber data sekunder dalam penelitian ini penulis memanfaatkan berita dari berbagai surat kabar, majalah, dan dokumen. Surat kabar yang menjadi sumber data yaitu SKH Kompas, Warta Ekonomi, dan The Australian, Herald Sun, The Age di Australia, serta surat kabar Agenda Daily di Malaysia.

Adapun untuk memperoleh data primer dalam penelitian kualitatif ini penulis menggunakan Informan yang terdiri dari dua kategori, yaitu informan kunci dan informan pendukung yang dipilih secara purposif berdasarkan aktivitas mereka yang dapat mengeksplorasi pengalamannya secara baik dalam melaksanakan diplomasi publik. Informan kunci, yaitu para pengurus "Koalisi untuk Kebebasan Informasi," Menteri Luar Negeri RI; Direktur Diplomasi Publik pada Direktorat Jenderal Informasi, Diplomasi Publik, dan Perjanjian Internasional Departemen Luar Negeri RI; Ketua Panitia Khusus RUU KMIP DPRRI, periode 1999-2004. Sedangkan informan pendukung terdiri dari pejabat UNESCO, Articel 19, akademisi Melbourne University, Deakin University, Monash University, pejabat pada Kedutaan Besar Malaysia di Indonesia, dan beberapa pakar hubungan internasional di Indonesia, Pemimpin Redaksi Surat Kabar Harian Kompas.

\section{Hasil Penelitian dan Pembahasan}

\subsection{Kegiatan "Koalisi untuk Kebebasan Informasi" dalam Diplomasi Publik}

Pada prinsipnya, kegiatan Koalisi terdiri dari kegiatan pengkajian, lobi dan kampanye. Beberapa kegiatan Koalisi yang dapat dikategorikan sebagai kegiatan diplomasi publik dapat dilihat dalam tabel 3.1.

Selama ini, bangsa Indonesia tidak tanggap dengan kemampuan ornop untuk melakukan tugastugas diplomasi yang dibutuhkan, padahal jika prinsip-prinsip public relations yang menggunakan pendekatan kegiatan secara demokratis dilakukan, setidaknya permasalahan kebutuhan dan pembangunan sarana diplomasi yang mengarah kepada terciptanya keterbukaan dan demokratisasi informasi dapat diwujudkan dengan mudah. Dari temuan ini dapat penulis visualisasikan seperti pada gambar 3.1.

\subsection{Kinerja "Koalisi untuk Kebebasan}

Sasaran utama kegiatan Koalisi untuk merealisasikan maksud dan tujuannya adalah memperjuangkan diundangkannya UndangUndang Kebebasan Memperoleh Informasi Publik. Konsepsi kebebasan memperoleh informasi, partisipasi publik, dan pemerintahan yang terbuka, dirumuskan oleh Koalisi dalam draf Rancangan Undang-Undang Kebebasan Memperoleh Informasi Publik (RUU-KMIP), yang diajukan 
Tabel 3.1 Kegiatan Koalisi yang Dapat Dikategorikan sebagai Kegiatan Diplomasi Publik

\begin{tabular}{|c|c|c|}
\hline No & Kegiatan & Sasaran \\
\hline 1 & Lobi & $\begin{array}{l}\text { Kedutaan asing yang telah memiliki undang-undang kebebasan } \\
\text { infoemasi }\end{array}$ \\
\hline 2 & Studi banding & $\begin{array}{l}\text { Negara-negara yang memiliki UU Kebebasan Informasi, antara } \\
\text { lain Swedia, Jepang, Australia, Thailand }\end{array}$ \\
\hline 3 & $\begin{array}{l}\text { Bantuan Tim Ahli Perumusan } \\
\text { RUU KMIP }\end{array}$ & Ahli-ahli internasional tentang kebebasan informasi \\
\hline 4 & $\begin{array}{l}\text { Menyelenggarakan Seminar } \\
\text { Internasional tentang KMI }\end{array}$ & $\begin{array}{l}\text { Ahli-ahli internasional tentang kebebasan informasi dan Omop } \\
\text { internasional }\end{array}$ \\
\hline 5 & $\begin{array}{l}\text { Menyelenggarkan Lokakarya, } \\
\text { diskusi, konsultasi regional }\end{array}$ & $\begin{array}{l}\text { Ahli-ahli internasional tentang kebebasan informasi dan Omop } \\
\text { internasional }\end{array}$ \\
\hline 6 & $\begin{array}{l}\text { Menghadiri seminar } \\
\text { internasional tentang KMI }\end{array}$ & Pembicra dan peserta seminar \\
\hline 7 & $\begin{array}{l}\text { Kerjasama dalam penerbitan } \\
\text { buku/information kit }\end{array}$ & Lembaga-lembaga/Ornop internasional \\
\hline 8 & Kampanye via media massa & $\begin{array}{l}\text { Wawancara Radio dan TV dengan ahli Ornop internasional, } \\
\text { Komisi I DPR RI, Pemerintah }\end{array}$ \\
\hline 9 & Penggunaan Website & Sosialisasi program \\
\hline
\end{tabular}

\section{Gambar 3.1 Implementasi Kegiatan Ornop melalui Pendekatan "Public Relations" dalam Proses Diplomasi Publik}

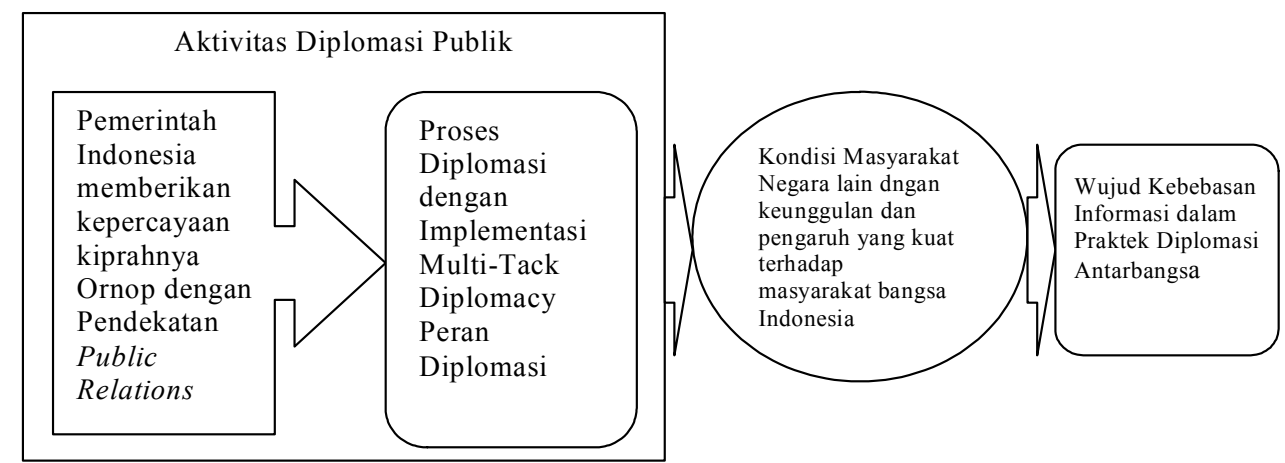

Sumber: Analisis Hasil Penelitian

Koalisi kepada DPR RI periode 1999-2004.

Koalisi memperjuangkan prinsip-prinsip pemerintahan yang transparan, partisipatif, dan akuntabel, sejalan dengan karakteristik good governance sebagaimana diidentifikasikan oleh UNDP. Sekalipun demikian, Koalisi tidak hanya mengandalkan adanya Undang-Undang Kebebasan Memperoleh Informasi Publik dari aspek legal formal, tetapi akan mengupayakan pula bagaimana undang-undang tersebut diimplementasikan, sehingga membawa manfaat bagi publik dan menjadikan pemerintahan yang transparan, partisipatif, dan akuntabel.

Undang-undang Kebebasan Memperoleh Informasi Publik hanya merupakan suatu instrumen, dan kemanfaatannya tergantung kepada adanya kesadaran masyarakat akan haknya atas informasi, kapasitas badan publik yang memadai dalam memenuhi hak atas informasi publik, serta tersedianya infrastruktur yang 


\section{Gambar 3.2. Alur Kegiatan Diplomasi Publik oleh "Koalsisi" Kebebasan Informasi}

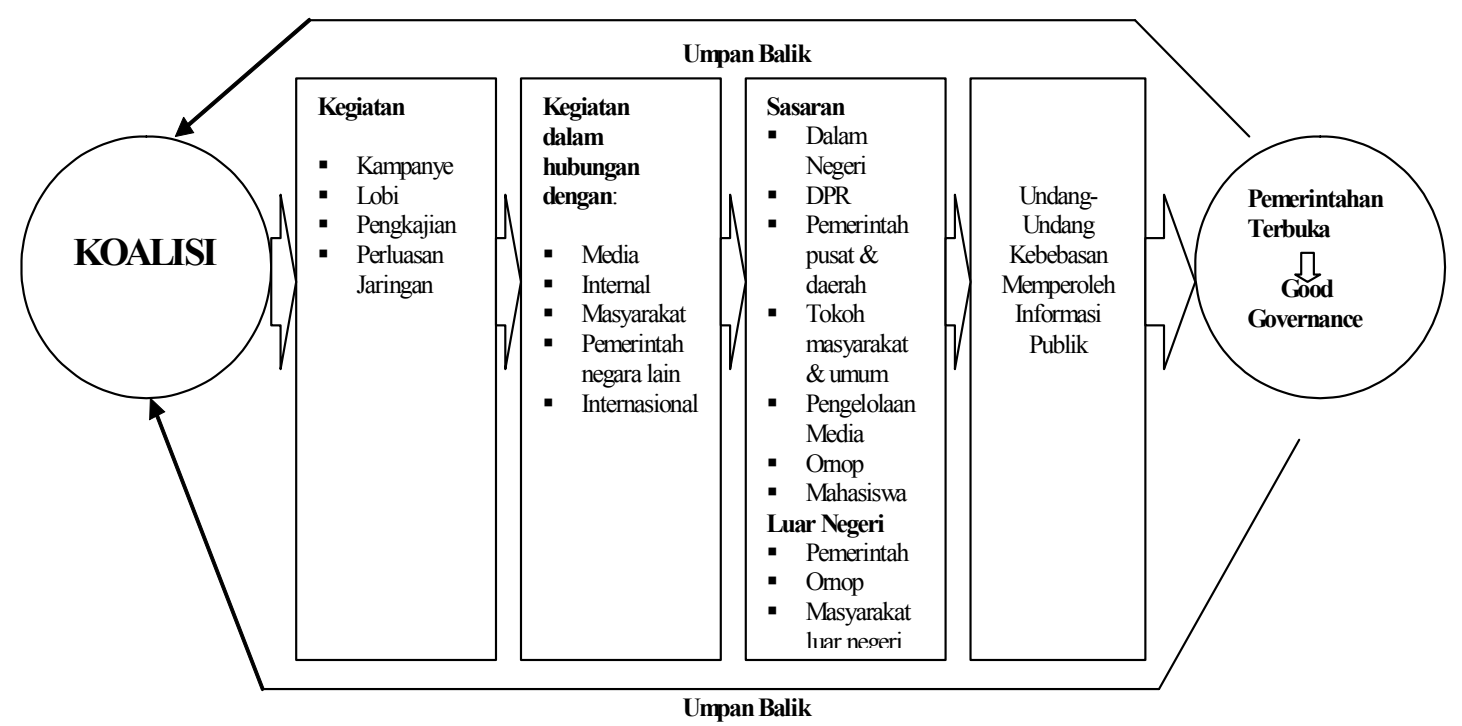

memadai untuk mengakses informasi.

Koalisi berhasil menyampaikan draf RUU Kebebasan Memperoleh Informasi Publik kepada DPR, sehingga menjadi usul inisiatif DPR setelah mendapat penyempurnaan oleh DPR. Dalam pembahasan RUU KMIP di DPR, Koalisi juga aktif memberikan sumbangan pemikiran untuk membahas Daftar Inventaris Masalah (DIM) yang dibahas DPR bersama pemerintah. Koalisi juga membahas langkah-langkah yang harus dilakukan setelah RUU KMIP disahkan menjadi UU KMIP, yaitu yang menyangkut permasalahan kapasitas badan publik yang bertanggung jawab dalam menyediakan informasi yang diperlukan publik, peningkatan kesadaran masyarakat terhadap haknya atas informasi yang perlu diketahui masyarakat, serta tersedianya sarana/prasarana yang memungkinkan masyarakat dapat mengakses informasi.

Koalisi telah turut memberikan andil dalam mendorong beberapa kabupaten/kota di Indonesia, melahirkan beberapa peraturan daerah (perda) tentang transparansi, kebebasan informasi, dan partisipasi publik, yang sejalan dengan semangat kebebasan memperoleh informasi publik di beberapa kabupaten/kota, propinsi, seperti pada Tabel 3.2.

Jika dilihat alur kegiatan diplomasi publik yang dilakukan "Koalisi untuk Kebebasan Informasi" dalam perwujudan good governance dapat dilihat pada gambar 3.2.

\subsection{Kegiatan Diplomasi Publik yang Dilakukan "Koalisi untuk Kebebasan Informasi" dalam pembangunan citra Indonesia}

Upaya yang dilakukan Koalisi memperjuangkan lahirnya Undang-undang Kebebasan Memperoleh Informasi Publik, yang bertujuan membangun pemerintahan yang terbuka menuju tatanan pemerintahan yang baik (good governance) dapat membangun citra yang baik bagi Indonesia. Citra dibangun oleh suatu realitas 
Tabel 3.2. Kabupaten /Kota/Propinsi yang telah Memiliki Perda tentang Transparansi dan Partisipasi

\begin{tabular}{|c|c|c|c|}
\hline No & Nama Daerah & Perda Nomor/Tgl. & Tentang \\
\hline 1 & $\begin{array}{l}\text { Kabupaten } \\
\text { Solok }\end{array}$ & $\begin{array}{l}5 \text { tahun 2004, tanggal } 29 \text { April } \\
2004\end{array}$ & $\begin{array}{c}\text { Transparansi Penyelenggaraan } \\
\text { Pemerintahan dan Partisipasi } \\
\text { Masyarakat }\end{array}$ \\
\hline 2 & $\begin{array}{l}\text { Kabupaten } \\
\text { Lebak }\end{array}$ & $\begin{array}{l}10 \text { tahun } 2004 \text { tanggal } 1 \text { Juni } \\
2004\end{array}$ & $\begin{array}{c}\text { Transparansi dan Partisipasi dalam } \\
\text { Penyelenggaraan Pemerintahan dan } \\
\text { Pengelolaan Pembangunan di } \\
\text { Kabupaten Lebak }\end{array}$ \\
\hline 3 & $\begin{array}{l}\text { Kabupaten } \\
\text { Bandung }\end{array}$ & $\begin{array}{l}06 \text { tahun } 2004 \text { tanggal } 20 \text { Agustus } \\
2004\end{array}$ & $\begin{array}{c}\text { Transparansi dan Partisipasi dalam } \\
\text { Penyelenggaraan Pemerintahan di } \\
\text { Kabupaten Bandung }\end{array}$ \\
\hline 4 & $\begin{array}{l}\text { Kabupaten } \\
\text { Magelang }\end{array}$ & $\begin{array}{l}10 \text { tahun } 2004 \text { tanggal } 15 \text { Maret } \\
2004\end{array}$ & Mekanisme Konsultasi Publik \\
\hline 5 & $\begin{array}{l}\text { Kabupaten } \\
\text { Tanah Datar }\end{array}$ & $\begin{array}{l}02 \text { tahun } 2005 \text { tanggal } 3 \text { Juni } \\
2005\end{array}$ & Transparansi dan Partisipasi \\
\hline 6 & $\begin{array}{l}\text { Kabupaten } \\
\text { Kebumen }\end{array}$ & $\begin{array}{l}53 \text { tahun } 2004 \text {, tanggal } \\
28 \text { Juni } 2004\end{array}$ & $\begin{array}{l}\text { Partisipasi Masyarakat dalam Proses } \\
\text { Kebijakan Publik }\end{array}$ \\
\hline 7 & $\begin{array}{l}\text { Kabupaten } \\
\text { Lamongan }\end{array}$ & $\begin{array}{l}07 \text { tahun } 2005 \text { tanggal } 1 \text { Agustus } \\
2005\end{array}$ & $\begin{array}{l}\text { Transparansi dalam Penyelenggaraan } \\
\text { Pemerintahan dan Partispasi } \\
\text { Masyarakat di Kabupaten Lamongan }\end{array}$ \\
\hline 8 & $\begin{array}{l}\text { Kabupaten } \\
\text { Boalemo }\end{array}$ & $\begin{array}{l}06 \text { tahun } 2004 \text { tanggal } 24 \text { Agustus } \\
2004 \\
07 \text { tahun } 2004 \text { tanggal } 24 \text { Agustus } \\
2004\end{array}$ & $\begin{array}{c}\text { Transparansi Pelayanan Publik dalam } \\
\text { Penyelenggaraan Pemerintahan di } \\
\text { Kabupaten Boalemo } \\
\text { Partisipasi masyarakat dalam } \\
\text { penyelenggaraan pembangunan dan } \\
\text { proses kebijakan publik }\end{array}$ \\
\hline 9 & $\begin{array}{l}\text { Kabupaten } \\
\text { Bolaang } \\
\text { Mongondo }\end{array}$ & $\begin{array}{l}04 \text { tahun } 2005 \text { tanggal } 14 \text { April } \\
2005 \\
05 \text { tahun } 2005 \text { tanggal } 14 \text { April } \\
2005\end{array}$ & $\begin{array}{c}\text { Partisipasi masyarakat dalam proses } \\
\text { pengambilan kebijakan publik } \\
\text { Transparansi Penyelenggaraan } \\
\text { Pemerintahan Daerah }\end{array}$ \\
\hline 10 & $\begin{array}{l}\text { Kabupaten } \\
\text { Takalar }\end{array}$ & $\begin{array}{l}02 \text { tahun } 2005 \text { tanggal } 19 \text { Agustus } \\
2005\end{array}$ & $\begin{array}{c}\text { Transparansi Penyelenggaraan } \\
\text { Pemerintahan dan Partisipasi } \\
\text { Masyarakat dalam pembangunan di } \\
\text { Kabupaten Takalar } \\
\end{array}$ \\
\hline 11 & Kota Gorontalo & $\begin{array}{l}03 \text { tahun } 2002 \text { tanggal } 13 \\
\text { Maret } 2002\end{array}$ & $\begin{array}{l}\text { Transparansi Penyelenggaraan } \\
\text { Pemerintahan Kota Gorontalo }\end{array}$ \\
\hline 12 & Kota Kendari & $\begin{array}{l}14 \text { tahun } 2003 \text { tanggal } 19 \text { Mei } \\
2003\end{array}$ & Kebebasan memperoleh informasi \\
\hline 13 & $\begin{array}{l}\text { Propinsi } \\
\text { Kalimantan } \\
\text { Barat }\end{array}$ & $\begin{array}{l}04 \text { tahun } 2005 \text { tanggal } 13 \text { Juni } \\
2005\end{array}$ & $\begin{array}{c}\text { Transparansi Penyelenggaraan } \\
\text { Pemerintahan Propinsi Kalimantan } \\
\text { Barat }\end{array}$ \\
\hline
\end{tabular}

Sumber: Koalisi, Google "Perda Online". 
dan persepsi terhadap realitas. Sekalipun citra tidak selalu harus sesuai dengan realitas, tetapi citra diperoleh dari persepsi tentang realitas. Citra Indonesia yang terpuruk setelah krisis ekonomi 1997, kemudian membawa keterpurukan di bidang politik pemahaman atas kenyataan sesungguhnya.

\subsection{Model Diplomasi Publik}

Penelitian ini menghasilkan temuan sebuah konstruksi baru dalam diplomasi yang

\section{Gambar. 3.3. Model Implementasi dari Diplomasi Total}

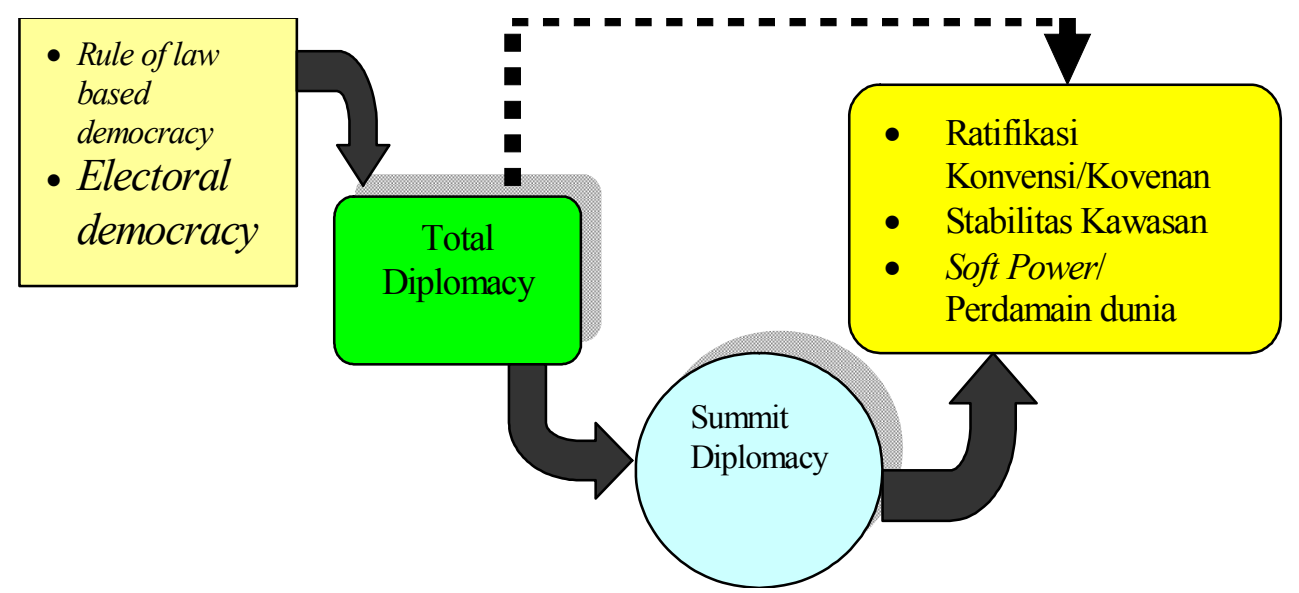

dan sosial budaya, telah memunculkan kekuatan reformasi dengan sasaran yang luas. Tuntutan reformasi menguat dan mengkristal dalam bentuk tuntutan mempercepat pemilu, mengubah UUD 1945, mengadili Soeharto, memberantas korupsi, kolusi, dan nepotisme, sebagai jalan untuk mengakhiri krisis. ${ }^{4}$

Undang-Undang Kebebasan Memperoleh Informasi Publik yang diperjuangkan Koalisi, akan mendorong terwujudnya pemerintahan yang terbuka. Pemerintahan yang terbuka dapat mencegah terjadinya praktek korupsi, kolusi, dan nepotisme, serta mendorong terwujudnya pemerintahan yang partisipatif dan akuntabel. Pemerintahan yang partisipatif dan akuntabel akan menghasilkan citra yang baik, baik oleh masyarakat di dalam negeri maupun oleh masyarakat di luar negeri. Citra dimaksud bukan citra bayangan, atau citra yang diharapkan yang lebih menyenangkan dari citra yang ada, tetapi citra yang benar berdasarkan pengalaman, pengetahuan, serta diperjuangkan bangsa Indonesia sebagaimana terlihat dalam bentuk Gambar 3.3.

Temuan lain yang menyangkut diplomasi publik untuk fokus-fokus terntentu dalam penelitian ini juga dapat penulis ketengahkan sebuah bentuk diplomasi multijalur, yang mampu mengarah kepada sebuah diplomasi total, Secara sederhana dapat dilihat pada Gambar 3.4.

Berdasarkan temuan-temuan dari hasil penelitian, maka model diplomasi publik yang dapat menyinergikan dan mengintegrasikan seluruh komponen bangsa untuk membangun persepsi yang mampu menghasilkan pembangunan citra Indonesia dapat dibangun oleh dua model yaitu Model Diplomasi Publik dengan Sistem Pelayanan Informasi Terintegrasi dan Berstruktur dan Model Diplomasi Publik dengan Sistem Pelayanan Informasi Pemberdayaan Publik.

Model "Sistem Pelayanan Informasi Terintegrasi dan Berstruktur" digambarkan sebagai berikut: 


\section{Gambar 3.4. Peran Aktor Pemerintah dan Nonpemerintah dalam Diplomasi Total}

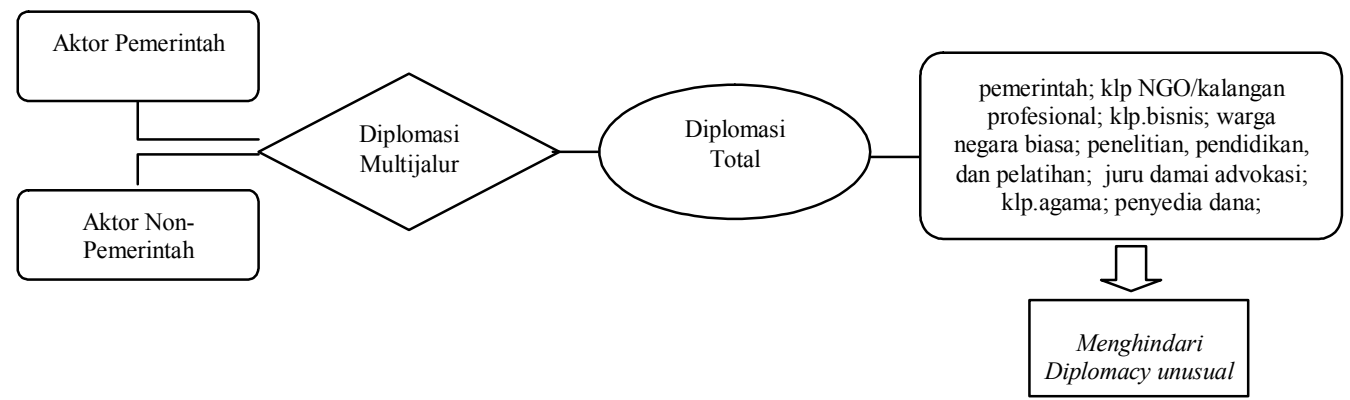

(1) Jalur yang digunakan dalam diplomasi adalah multi jalur (multitrack diplomacy).

(2) Adanya hubungan (koneksitas) antara pemerintah pusat dalam hal ini presiden dengan instansi pemerintah di tingkat pusat, presiden dengan instansi nonpemerintah di tingkat pusat (ornop yang bekerja sama dengan institusi di luar negeri), dan antara presiden dengan pemerintah daerah. Presiden dapat menunjuk instansi pemerintah di tingkat pusat yang bertugas mengoordinasikan dan menyinergikan informasi pada tingkat pusat sebagai bahan diplomasi publik. Demikian pula bagi gubernur, bupati, dan walikota.

(3) Adanya petugas yang memiliki kemampuan di bidang teknologi informasi dan jabatan yang jelas untuk menunjukkan tanggung jawabnya. Ketentuan bahwa pejabat hubungan masyarakat pada instansi pemerintah sebagai pejabat fungsional diperlukan pengembangan melalui pendidikan dan pelatihan.

(4) Adanya materi atau substansi masalah untuk diinformasikan. Beragam potensi sumber daya alam yang dapat diolah menjadi komoditi ekonomi, produk-produk unggulan daerah yang dapat dijual ke luar negeri, kalau tidak terkoordinasikan dalam penyampaian informasi, tidak akan terinformasikan secara luas dan menyeluruh.. ${ }^{5}$

(5) Adanya kerangka kerja legal yang berupa ketentuan peraturan perundang-undangan yang mendukung terintegrasinya informasi melalui penggunaan teknologi informasi.

(6) Adanya pengolahan umpan balik dalam proses penyampaian dan penerimaan informasi untuk mengindikasikan pemahaman oleh penerima. Informasi tidak hanya disampaikan untuk diterima tetapi juga untuk difahami.

(7) Pelayanan secara terintegrasi dan berstruktur terdiri dari pelayanan informasi di pemerintah tingkat kabupaten/kota ke pemerintah propinsi sampai ke pemerintah tingkat pusat. Pada masing-masing struktur ditunjuk istitusi pemerintah yang mengoordinasikan dan mensinergikan pelayanan informasi yang menjadi focal point, sehingga merupakan pelayanan informasi "satu pintu" (one stop information service), di samping bertindak sebagai navigator pelayanan informasi.

Model diplomasi publik dengan sistem pelayanan informasi terintegrasi dan berstruktur ditampilkan pada Gambar 3.5.

Model diplomasi publik melalui sistem pelayanan informasi pemberdayaan publik, adalah sebuah model dengan gambaran sebagai berikut:

(1) Diplomasi publik dilaksanakan melalui aspek people-to-people contact atau interaksi antara kelompok swasta dan kepentingan suatu negara dengan kelompok swasta dan kepentingan negara lain.

(2) Merupakan konsep untuk mengaktualisasikan potensi aktor nonnegara yang berupa 
Gambar 3.5.

Model Diplomasi Publik dengan Sistem Pelayanan Informasi Terintegrasi Terstuktur

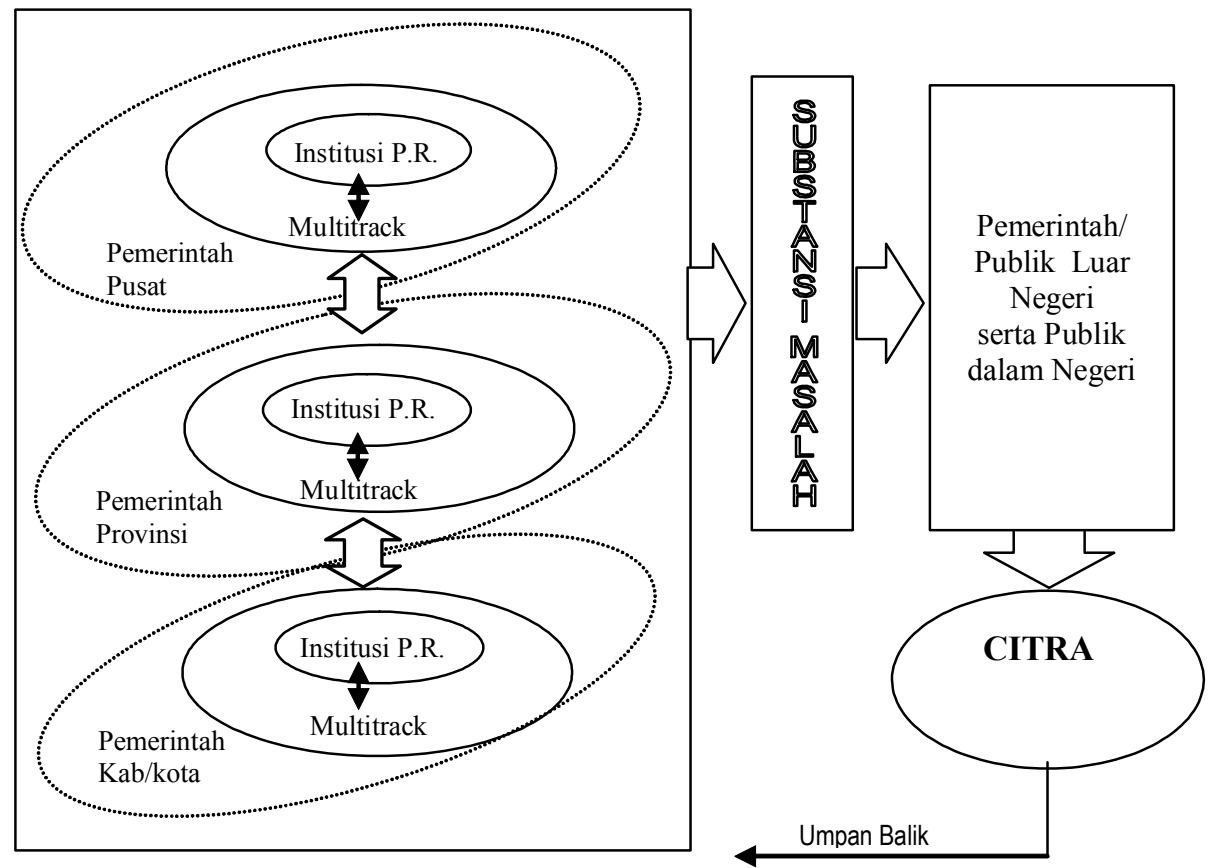

kekuatan, kemampuan ornop atau kelompok masyarakat, merevitalisasi kemampuan yang dimiliki untuk melaksanakan kegiatan diplomasi publik.

(3) Proses pemberdayaan mengandung dua kecenderungan, yaitu proses yang menekankan kepada pemberian atau pengalihan sebagian kekuasaan, kekuatan, atau kemampuan kepada masyarakat agar menjadi lebih berdaya, dan proses menstimulasi, mendorong, atau memotivasi, agar masyarakat mempunyai kemampuan untuk memberdayakan diri.

(4) Pemberdayaan dimaksudkan untuk memecahkan masalah sebagai tantangan yang harus dihadapi di bidang legitimasi politis, legalitas, keberlanjutan finansial, kompotensi profesionalitas, dan kredibilitas sosial LSM/ $N G O$ sebagai aktor nonnegara.

Model diplomasi publik dengan sistem pelayanan informasi pemberdayaan publik, ditampilkan pada Gambar 3.6. berikut.

\section{Kesimpulan dan Saran}

\subsection{Kesimpulan}

Dari hasil temuan penelitian dan pembahasan maka dapat dirumuskan beberapa kesimpulan sebagai berikut:

(1) Kegiatan "Koalisi untuk Kebebasan Informasi” dalam berbagai kategori termasuk kegiatan diplomasi publik melalui pendekatan public relations..

(2) Kinerja "Koalisi untuk Kebebasan Informasi" yang difokuskan kepada memperjuangkan lahirnya Undang-Undang Kebebasan Memperoleh Informasi Publik, menunjang terwujudnya good governance.

(3) Diplomasi publik yang dilakukan "Koalisi untuk Kebebasan Informasi" melalui 


\section{Gambar 3.6. Model Diplomasi Publik dengan Sistem Pelayanan Informasi Pemberdayaan Publik}

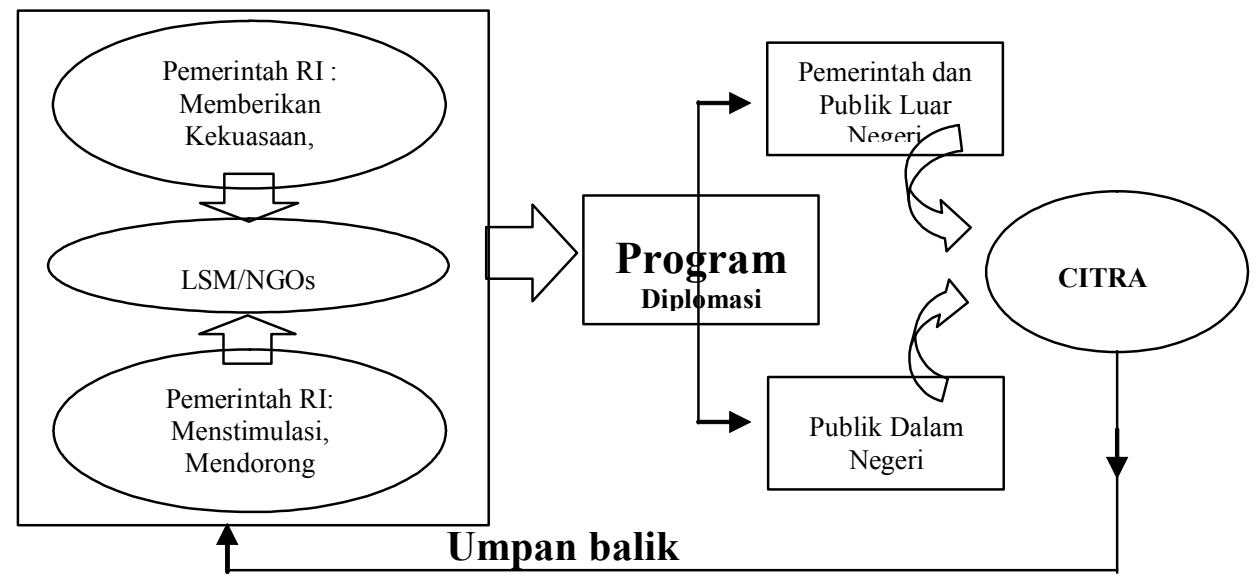

advokasinya telah dapat membangun citra Indonesia, ditandai, antara lain, dengan terselenggaranya berbagai peraturan daerah (Perda) mengenai penyelenggaraan pemerintahan daerah secara partisipatif dan transparan.

(4) Model-model diplomasi publik yang dapat menyinergikan dan mengintegrasikan segenap komponen bangsa untuk membangun citra Indonesia adalah model diplomasi publik melalui pendekatan public relations yang terdiri dari: pertama, model diplomasi publik dengan sistem pelayanan informasi terintegrasi dan berstruktur, serta kedua model diplomasi publik dengan sistem pelayanan informasi pemberdayaan publik. Pada era globalisasi, peran aktor nonnegara (non-state actor) dalam diplomasi publik makin mengemuka, maka model yang sangat berpotensi untuk dikembangkan adalah model diplomasi publik dengan sistem pelayanan informasi pemberdayaan publik.

\subsection{Saran}

\subsubsection{Saran Teoretis}

(1) Aplikasi teori public relations diharapkan lebih terfokus pada upaya membangun pengertian dan hubungan baik dengan publik tidak hanya untuk kepentingan organisasi, tetapi juga untuk kepentingan kelompok, bahkan individu yang berinteraksi dengan publik atau pemerintahan.

(2) Konsep dan teori diplomasi publik maupun public relations yang memiliki prinsip dan bidang kajian dalam bentuk penelitian, perencanaan, pelaksanaan, dan evaluasi program, hendaknya dapat dijadikan kerangka pemikiran diperolehnya pemahaman bagi terwujudnya institusi yang menjadi focal point dalam menerima, mengolah, dan menyampaikan informasi sehingga mampu menerapkan konsep good governance.

(3) Anggapan bahwa diplomasi publik berbeda dengan public relations karena public relations dapat mengarah kepada persuasi yang hebat, atau bahkan menjadi alat propaganda. Sedangkan diplomasi publik untuk mempererat hubungan antara suatu negara dengan publik di luar negeri dan juga publik dalam negeri dapat disangkal dengan teori public relations yang ideal adalah yang didasarkan kepada fakta, sehingga pemolesan suatu citra 
merupakan penghianatan terhadap profesi public relations.

(4) Diplomasi publik yang dilakukan oleh pemerintah suatu negara kepada publik di luar negeri dan masyarakat negara tersebut kepada masyarakat negara lain hendaknya mampu melibatkan Ornop/LSM yang merupakan bagian masyarakat serta termasuk salah satu elemen masyarakat dalam diplomasi multi jalur.

\subsubsection{Saran Praktis}

(1) Pemerintah Pusat dan Pemerintah Daerah RI perlu menunjuk institusi atau lembaga yang menjadi focal point kegiatan public relations. Institusi atau lembaga yang menjadi focal point adalah organisasi yang berfungsi sebagai pelayanan informasi satu pintu dan bertindak sebagai navigator informasi.

(2) Institusi/lembaga yang ditunjuk untuk menjadi focal point dalam menerima, mengolah, dan menyampaikan informasi perlu memiliki kewenangan untuk berhubungan langsung dengan pimpinan keseluruhan organisasi yang memiliki kewenangan dalam menetapkan kebijakan, karena pejabat public relations bertindak sebagai representasi pimpinan untuk menyampaikan informasi kepada publik.

(3) Pemerintah RI perlu mengidentifikasi komponen-komponen masyarakat yang dapat disinergikan dan diintegrasikan dalam pelaksanaan diplomasi publik. Pengintegrasian dan penyinergian dilakukan secara berstruktur, mulai di tingkat pemerintah pusat, propinsi, kabupaten/kota.

(4) Untuk memberdayakan masyarakat dalam melaksanakan diplomasi publik, pemerintah beserta komponen masyarakat lainnya perlu memperbanyak kegiatan-kegiatan pendidikan dan pelatihan, pembelajaran (learning by do- ing), sosialisasi, tentang pentingnya elaksanakan prinsip-prinsip transparansi, partisipasi, dan akuntabilitas.

\section{Catatan Akhir}

1 Kompas Cyber Media: Melalui <http:// www.kompas.com/ver $1 /$ ekonomi/0609/22/ 084825.htm>

2 Ratna Shofi Inayati, dkk., 2002. Politik Luar Negeri Indonesia Pasca Soeharto: Diplomasi Pemulihan Ekonomi Nasional, Jakarta. LIPI, hlm. 76.

3 Eldridge dalam Anderson H. 2004. Good Governance and NGOs in Contemporary Indonesia, Clayton: Monash University, hlm. 3.

4 Jakob Tobing. 2002. "Pengantar Materi Sosialisasi UUD 45 Hasil Amandemen." Makalah.

5 Kompas, 29 Desember 2006. hlm. 1 dan 15.

\section{Daftar Pustaka}

Elridge dalam Anderson H. 2004. Good Governance and NGOs in Contemporary Indonesia. Monash University.

Inayati, Ratna Shofi dkk. 2002. Politik Luar Negeri Indonesia Pasca Soeharto: Diplomasi Pemulihan Ekonomi Nasional. Jakarta: P2P LIPI. hlm. 76.

Kompas Cyber Media. Melalui: $\underline{\text { http:// }}$ www.kompas.com/ver1/ ekonomi/0609/22/ 084825.htm

Kompas, 29 Desember 2006.

Rahkmat, Jalaluddin. 2000. Psikologi Komunikasi. Bandung Remaja Rosdakarya.

Tobing, Jakob. 2002. "Pengantar Materi Sosialisasi UUD 1945 Hasil Amandemen.” Jakarta: Makalah. 
